\title{
Progesterone induces NFkB DNA binding activity through a PI3K/Akt-dependent pathway in MCF-7 breast cancer cells
}

\author{
Fernando Candanedo-Gonzalez, Octavio Galindo-Hernandez, Nathalia Serna-Marquez, \\ Roberto Espinosa-Neira, Adriana Soto-Guzman, Pedro Cortes-Reynosa, Eduardo Perez Salazar \\ Departamento de Biologia Celular. Cinvestav-IPN. Av IPN \# 2508. San Pedro Zacatenco. Mexico, DF. 07360. Mexico
}

Email address:

jperez@cell.cinvestav.mx (E. P. Salazar)

\section{To cite this article:}

Fernando Candanedo-Gonzalez, Octavio Galindo-Hernandez, Nathalia Serna-Marquez, Roberto Espinosa-Neira, Adriana Soto-Guzman, Pedro Cortes-Reynosa, Eduardo Perez Salazar. Progesterone Induces NFkB DNA Binding Activity through a PI3K/Akt-Dependent Pathway in MCF-7 Breast Cancer Cells. Cancer Research Journal. Vol. 2, No. 4, 2014, pp. 63-69. doi: 10.11648/j.crj.20140204.11

\begin{abstract}
Progesterone (PG) is a steroid hormone that regulates normal reproductive functions including uterine and mammary gland development. The PG receptor belongs to the nuclear receptor superfamily of ligand dependent transcription factors that mediates gene expression, however, it also promotes cell signaling pathways through a non-genomic pathway including the activation of PI3K/Akt and Src/ERK1/2 pathways. However the role of PG in NFKB-DNA complex formation remains to be studied. We demonstrate here that PG induces Akt2 activation and an increase of NFKB DNA binding activity in MCF-7 breast cancer cells. Akt2 activation requires PI3K activity, whereas increase of NFkB DNA binding activity requires $\mathrm{PI} 3 \mathrm{~K}, \mathrm{mTOR}, \mathrm{Akt}$, Src, and G-proteins activity, as well as the integrity of cytoskeleton. In summary, our findings demonstrate that PG induces an increase of NFKB DNA binding activity in MCF-7 cells.
\end{abstract}

Keywords: Breast Cancer, Progesterone, PI3K/Akt, NFkB, MCF-7

\section{Introduction}

Epidemiological and clinical studies demonstrate that administration of progesterone (PG) is associated with an increased risk of developing postmenopausal breast cancer $[1,2]$. In addition, clinical studies demonstrate that $\sim 10 \%$ of estrogen-receptor-negative (ER-) breast cancers are PG-receptor-positive (PR+), and these tumors mainly affect women under 50 years of age [3, 4].

PG is a steroid hormone that regulates normal reproductive functions, including uterine and mammary gland development, as well as the signals required for sexually responsive behavior in the brain. The PG receptor (PR) belongs to the nuclear receptor superfamily of ligand dependent transcription factors that mediates gene expression (genomic pathway). However, PG also mediates non-genomic pathways including the activation of phosphatidylinositol 3-kinase (PI3K)/Akt and the c-Src/extracellular signal regulated kinase 1/2 (ERK1/2) pathways $[5,6]$.

The nuclear factor-kappa $\mathrm{B}(\mathrm{NF \kappa B})$ is a family of transcription factors, its common form is p50/Rel A and regulates the expression of a wide range of genes that are critical for survival and proliferation. $\mathrm{NF \kappa B}$ is required for normal lobuloalveolar development of mammary gland; however it is overexpressed in different stages of breast cancer progression. Particularly, a high activity of NFKB has been reported in $\sim 86 \%$ of Her-2 positive breast tumors $[7,8]$.

In the present study, we demonstrate that PG induces Akt2 activation and an increase of NFKB DNA binding activity in MCF-7 cells. Akt2 activation requires PI3K activity, whereas increase of NFKB DNA binding activity requires PI3K, mTOR, Akt, Src and G-proteins activity, as well as the integrity of cytoskeleton.

\section{Materials and Methods}

\subsection{Chemicals}

PG, Akt 1/2 kinase inhibitor A6730, pertussis toxin (PTX) and cholera toxin (CTX) were from Sigma (St, Louis, MO). Wortmaninn, rapamycin, PP2 and PP3 were from Calbiochem (San Diego, CA). Akt2 antibody (Ab) F-7 was 
obtained from Santa Cruz Biotechnology (Santa Cruz, CA). Phosphospecific Ab to Thr-308 of Akt 244F9 (anti-p-Akt) was obtained from Cell Signaling (Danvers, MA). $\left[\gamma^{32} \mathrm{P}\right]$ ATP was obtained from Perkin-Elmer (Boston, MA).

\subsection{Cell culture}

The human MCF-7 breast cancer cells were cultured in Dulbecco's modified Eagle's medium (DMEM) supplemented with $3.7 \mathrm{~g} / \mathrm{l}$ sodium bicarbonate, 5\% fetal bovine serum (FBS), in a humidified atmosphere containing $5 \% \mathrm{CO}_{2}$ and $95 \%$ air at $37{ }^{\circ} \mathrm{C}$. For experimental purposes, cells were starved in DMEM without FBS for 12 $\mathrm{h}$ before treatment with inhibitors and/or PG.

\subsection{Cell stimulation}

After starvation, MCF-7 cells were washed twice with DMEM without FBS, equilibrated in the same medium at $37{ }^{\circ} \mathrm{C}$ for at least $30 \mathrm{~min}$, and then treated with inhibitors and/or PG for the times and concentrations indicated. We used confluent cultures of cells grown in 60-mm dishes containing $3 \mathrm{ml}$ of DMEM for each experimental condition. The stimulation was terminated by aspirating the medium and nuclear extracts were obtained or cells were solubilized in $0.5 \mathrm{ml}$ of ice-cold radioimmune precipitation assay (RIPA) buffer containing $50 \mathrm{mM}$ HEPES, $\mathrm{pH} 7.4,150 \mathrm{mM} \mathrm{NaCl}, 1$ mM EGTA, $1 \mathrm{mM}$ sodium orthovanadate, $100 \mathrm{mM} \mathrm{NaF}, 10$ $\mathrm{mM}$ sodium pyrophosphate, $10 \%$ glycerol, $1 \%$ Triton $\mathrm{X}-100$, $1 \%$ sodium deoxycholate, $1.5 \mathrm{mM} \mathrm{MgCl} 2,0.1 \% \mathrm{SDS}$ and 1 $\mathrm{mM}$ phenyl methylsulfonyl fluoride (PMSF).

\subsection{Western blotting}

Equal amounts of protein were separated by SDS-PAGE using $10 \%$ separating gels followed by transfer to nitrocellulose membranes. After transfer, membranes were blocked using 5\% non-fat dried milk in phosphate buffered saline (PBS), pH 7.2, and incubated overnight at $4{ }^{\circ} \mathrm{C}$ with the primary $\mathrm{Ab}$. The membranes were washed three times with PBS $/ 0.1 \%$ Tween 20 and then incubated with secondary $\mathrm{Ab}(1: 5000)$ for $2 \mathrm{~h}$ at $22^{\circ} \mathrm{C}$. After washing three times with PBS/0.1\% Tween 20 , the immunoreactive bands were visualized using ECL detection reagents. Autoradiograms were scanned and the labeled bands were quantified using the Image J software (Jandel Scientific).

\subsection{Preparation of nuclear extracts}

Nuclear extracts were prepared as described previously [9]. Briefly, $1.5 \times 10^{6}$ cells were lysed with $0.1 \%$ nonionic detergent Nonidet P40 in Buffer A $(10 \mathrm{mM}$ Tris- $\mathrm{HCl}, \mathrm{pH}$ 7.4, $10 \mathrm{mM} \mathrm{NaCl}, 6 \mathrm{mM} \mathrm{MgCl}, 10 \mathrm{mM} \mathrm{NaF}, 1 \mathrm{mM}$ $\mathrm{Na}_{3} \mathrm{VO}_{4}, 1 \mathrm{mM}$ DTT, $1 \mathrm{mM}$ PMSF). Lysates were pelleted at $2600 \mathrm{rpm}$ for $15 \mathrm{~min}$ and resuspended in Buffer B (20 mM HEPES, pH 7.9, $420 \mathrm{mM} \mathrm{NaCl}, 20 \%$ glycerol $1.5 \mathrm{mM}$ $\mathrm{MgCl}_{2}, 0.2 \mathrm{mM}$ EDTA, $1 \mathrm{mM} \mathrm{Na} \mathrm{VO}_{4}, 10 \mathrm{mM} \mathrm{NaF}, 1 \mathrm{mM}$ DTT, $0.2 \mathrm{mM}$ PMSF). Nuclear extracts were recovered by centrifugation at $14000 \mathrm{rpm}$ for $15 \mathrm{~min}$ at $4{ }^{\circ} \mathrm{C}$ and the protein level of each sample was determined by the micro
Bradford protein assay.

\subsection{Electrophoretic mobility shift assay (EMSA)}

Double-stranded oligonucleotide containing specific binding sites for NFKB 5'-AGCTAAGGGACTTTCCGCTGGGGACTTTCCAGG3', was used as probe [10]. A total amount of 20 pmol of annealed NF $\kappa$ B oligonucleotide was labeled with $\left[\gamma^{32} \mathrm{P}\right]$ ATP using T4 polynucleotide kinase. The ${ }^{32} \mathrm{P}$-labeled oligonucleotide probe $(\sim 1 \mathrm{ng})$ was incubated with $5 \mu \mathrm{g}$ of nuclear extract in a reaction mixture containing $13 \mu \mathrm{g}$ of poly (dI-dC), 0.25 M HEPES, pH 7.5, 0.6 M KCl, $50 \mathrm{mM}$ $\mathrm{MgCl}_{2}, 1 \mathrm{mM}$ EDTA, $7.5 \mathrm{mM}$ DTT, and 9\% glycerol for 20 min at $4{ }^{\circ} \mathrm{C}$. One hundred-fold excess of unlabeled NFkB probe was used as specific competitor. The samples were fractionated on a $6 \%$ polyacrylamide gel in $0.5 \mathrm{X}$ Tris borate-EDTA buffer. Gels were dried and they were analyzed by autoradiography.

\subsection{Statistical analysis}

Results are expressed as mean \pm S.D. Data were statistically analyzed using one-way ANOVA and the pairwaise comparisons were performed using Newman-Keuls multiple comparisons test. Statistical probability of $\mathrm{P}<0.05$ was considered significant.

\section{Results}

\subsection{PG induces Akt2 activation in MCF-7 Cells}

First, we examined whether PG promotes Akt2 activation in MCF-7 cells. Akt2 activation was analyzed by using its phosphorylation at Thr-309 [11]. Cultures of MCF-7 cells were treated with $100 \mathrm{nM}$ PG for various times and lysed. Cell lysates were immunoprecipitated with anti-Akt2 Ab and the immune complexes were analyzed by SDS-PAGE followed by Western blotting with anti-p-Akt Ab, which recognizes the phosphorylation on Thr-308 and Thr-309 of Akt1 and Akt2 respectively. As shown in Fig. 1A (upper panel), treatment of cells with PG induced an increase on Akt2 phosphorylation at Thr-309 (p-Akt2) that reached a maximum between 15 and $30 \mathrm{~min}$ of treatment. Western blotting with anti-Akt2 $\mathrm{Ab}$ of the same membrane was used as loading control (Fig. 1A, lower panel).

Akt is the primary downstream mediator of PI3K signaling, whereas mTOR activates Akt and then promotes proliferation and survival $[12,13]$. We determined whether Akt 2 activation requires PI3K and mTOR activity. MCF-7 cells were treated for $1 \mathrm{~h}$ with $60 \mathrm{nM}$ wortmannin or 100 $\mathrm{nM}$ rapamycin, which are selective inhibitors of PI3K and mTOR respectively [14], and then stimulated with $100 \mathrm{nM}$ PG for another $15 \mathrm{~min}$ and cells were lysed. Cell lysates were immunoprecipitated with anti-Akt $2 \mathrm{Ab}$, followed by Western blotting with anti-p-Akt Ab. Our results showed that $\mathrm{p}-\mathrm{Akt}$ induced by $\mathrm{PG}$ required PI3K activity, however it did not require mTOR activity (Fig. 1B) 

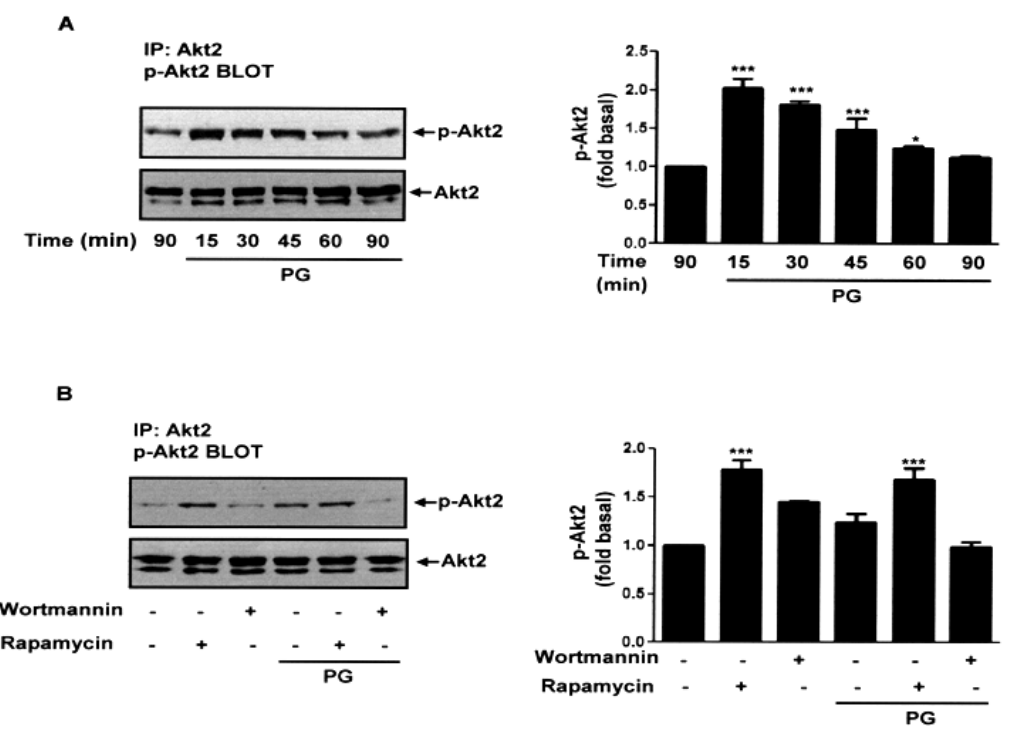

Figure 1. Progesterone induces Akt2 activation trough a PI3K-dependent pathway in MCF-7 cells. Panel A. MCF-7 cells were treated with $100 \mathrm{nM}$ progesterone (PG) for various times and lysed. Panel B. MCF-7 cells were treated for $1 \mathrm{~h}$ without (-) or with (+) $60 \mathrm{nM}$ wortmannin or $100 \mathrm{nM}$ rapamycin, stimulated with $100 \mathrm{nM} P \mathrm{P}$ for 15 min and lysed. Cell lysates were analyzed by immunoprecipitation with anti-Akt2 Ab followed by Western blotting with anti-p-Akt Ab. The graphs represent the mean \pm S.D. and are expressed as fold of $p$-Akt2 above unstimulated cells. Asterisks denote comparisons made to unstimulated cells. ${ }^{* * *} P<0.001$.

A)

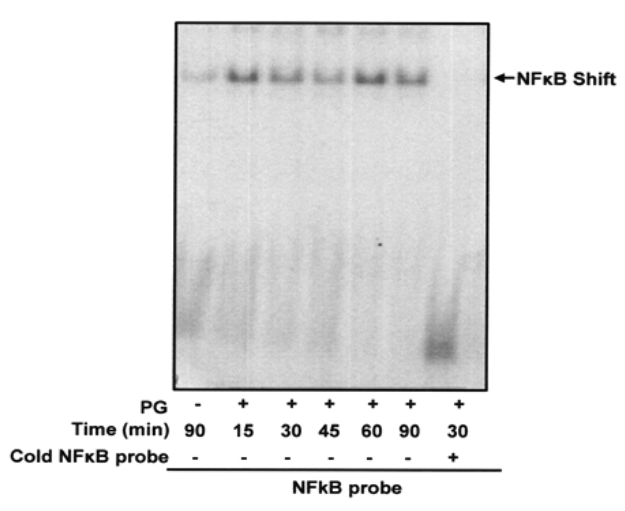

B)

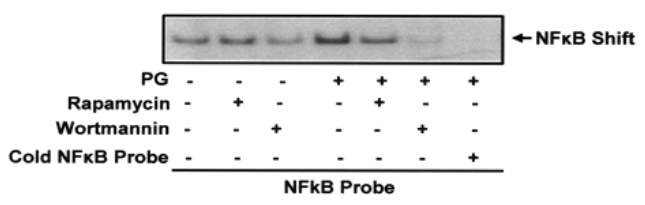

c)

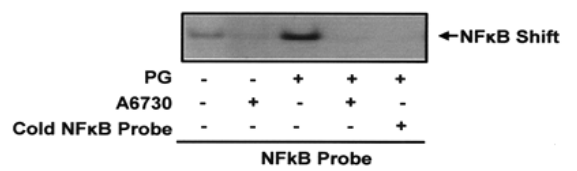

Figure 2. $P G$ induces $N F K B$ DNA binding activity through a PI3K/Akt-dependent pathway. Panel A. MCF-7 cells were treated with 100 $n M P G$ for various times and nuclear extracts were obtained. Panel $B$. $M C F-7$ cells were treated for $1 \mathrm{~h}$ without (-) or with (+) $60 \mathrm{nM}$ wortammin or $100 \mathrm{nM}$ rapamycin, stimulated with $100 \mathrm{nM} P$ P for 15 min and nuclear extracts were obtained. Panel C. MCF-7 cells were treated for $1 \mathrm{~h}$ without (-) or with (+) $2 \mu M$ A6730, stimulated with $100 \mathrm{nM} P G$ for 15 min and nuclear extracts were obtained. $N F K B$ DNA binding activity was analyzed by EMSA. One control included EMSA reactions with 100 fold-excess of cold $N F K B$ as competitor. The autoradiograms shown are representative of at least three independent experiments.

\subsection{PG induces NFKB-DNA complex formation in MCF-7 cells}

$\mathrm{NF} \kappa \mathrm{B}$ is a transcription factor that plays an important role in oncogenesis [15]. We determined whether PG induces NF $\kappa B-D N A$ complex formation. MCF-7 cells were treated with $100 \mathrm{nM}$ PG for various times and nuclear extracts were obtained. EMSAs were performed using nuclear extracts and a radiolabeled oligonucleotide probe representing a canonical NFאB binding site. As illustrated in Fig. 2A, a weak specific NFKB-DNA complex was observed in untreated cells, however treatment with $\mathrm{PG}$ significantly increased the DNA binding activity of $\mathrm{NF \kappa B}$ in a time-dependent manner, which reached a maximum at 60 min of treatment. The specificity of these complexes was demonstrated by inhibition of binding in the presence of a cold competitor.

Since PG induced Akt 2 activation, we determined the role of PI3K, Akt and mTOR in NFKB DNA binding activity induced by PG. MCF-7 cells were treated for $1 \mathrm{~h}$ with $60 \mathrm{nM}$ wortmannin or $100 \mathrm{nM}$ rapamycin, stimulated with $100 \mathrm{nM}$ PG for 15 min, nuclear extracts were obtained and EMSAs were performed. Our results showed that treatment with PI3K and mTOR inhibitors inhibited NFאB DNA binding activity induced by PG (Fig. 2B).

Next, we determined whether NFKB DNA binding activity induced by $\mathrm{PG}$ requires Akt activity. Cultures of MCF-7 cells were treated for $1 \mathrm{~h}$ with $2 \mu \mathrm{M}$ A6730, which is a selective inhibitor of Akt1/2 and has been used previously in breast cancer cells [16], and then cells were stimulated with $100 \mathrm{nM}$ PG for $15 \mathrm{~min}$, nuclear extracts were obtained and EMSAs were performed. As illustrated in Fig. 2C, treatment with Akt inhibitor completely inhibited NFkB DNA binding activity induced by PG. 


\subsection{Role of $S r c, G$ proteins activity and the cytoskeleton integrity on the increase of NFKB DNA binding activity induced by $P G$}

Since PG induces Src activation [17]. We determined the role of Src activity on NFKB DNA binding activity induced by PG. Cultures of MCF-7 cells were treated for $1 \mathrm{~h}$ with $10 \mu \mathrm{M}$ PP2, which is a selective inhibitor of Src family members, or with PP3, an inactive analog of PP2, and then stimulated with $100 \mathrm{nM}$ PG for $15 \mathrm{~min}$. Nuclear extracts were obtained and EMSAs were performed. As illustrated in Fig. 3A, treatment with PP2 inhibited NFKB DNA binding activity induced by $\mathrm{PG}$, whereas treatment with PP3 did not inhibit the NFKB DNA binding activity.

Next, we determined whether NFKB DNA binding activity requires the activity of $\mathrm{G}$ proteins. We studied the effect of PTX, and inhibitor of Gi/Go proteins, and CTX, a toxin that catalyzes the ADP-ribosylation of the $\alpha$-subunit of the Gas, reducing its GTPase activity and activating the $\alpha$-subunit $[18,19]$. Cultures of MCF-7 cells were treated for $12 \mathrm{~h}$ with $100 \mathrm{ng} / \mathrm{ml}$ PTX or $100 \mathrm{ng} / \mathrm{ml} \mathrm{CTX}$, and stimulated with $100 \mathrm{nM}$ PG for $15 \mathrm{~min}$. Nuclear extracts were obtained and EMSAs were performed. As illustrated in Fig. 3B, treatment with PTX partly inhibited NFкB-DNA complex formation, whereas treatment with CTX completely inhibited NFKB DNA binding activity induced by PG.

In order to determine the contribution of cytoskeleton in the NFאB DNA binding activity induced by PG, we determined the effect of colchicine and cytochalasin D, which promote the disappearance of microtubules and disrupt the organization of actin fibers respectively. Cultures of MCF-7 cells were treated for $1 \mathrm{~h}$ with $10 \mu \mathrm{M}$ colchicine or $2.4 \mu \mathrm{M}$ cytochalasin $\mathrm{D}$, and then stimulated with $100 \mathrm{nM}$ PG for $15 \mathrm{~min}$, nuclear extracts were obtained and EMSAs were performed. Our results showed that treatment with colchine inhibited the NFKB DNA binding activity induced by $\mathrm{PG}$, whereas treatment with cytochalasin D did not inhibit the NFKB-DNA complex formation (Fig. 3C).

\section{Discussion}

PG regulates breast development, function and differentiation, because it is able to stimulate proliferation or inhibit growth and promote differentiation [20, 21]. Moreover, it has been suggested that PG plays an important role in development and progression of breast cancer because postmenopausal women under treatment with estrogens and PG present an increased incidence of breast cancer development $[1,22]$. However, the signal transduction pathways mediated by PG have been mainly studied by using progestin, which is a synthetic progestogen with progestinic effects similar to $P G$, whereas the signal transduction pathways mediated by PG have been poorly studied.

The PI3K/Akt pathway regulates a wide variety of biological processes including migration, proliferation, growth, survival, angiogenesis and cancer [23, 24]. The PI3Ks are a family of kinases that generate a number of

A)

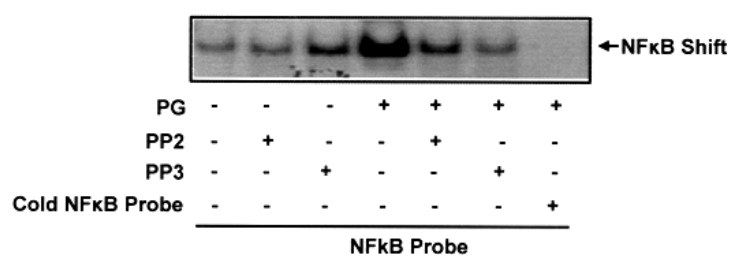

B)

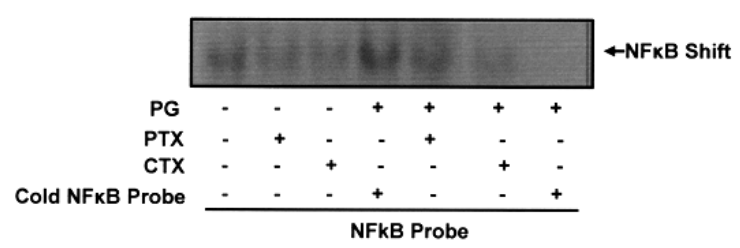

c)

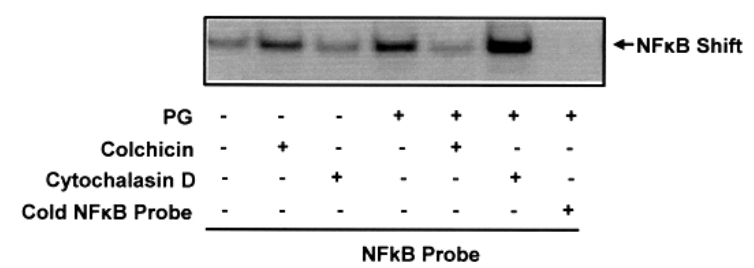

Figure 3. Role of Src, cytoskeleton integrity and G-proteins on NFKB DNA binding activity induced by PG. Panel A. MCF-7 cells were treated for $1 \mathrm{~h}$ without (-) or with (+) $10 \mu M$ PP2 or $10 \mu M$ PP3, stimulated with $100 \mathrm{nM} P G$ for $15 \mathrm{~min}$ and nuclear extracts were obtained. Panel B. $\mathrm{MCF}-7$ cells were treated for $12 \mathrm{~h}$ without (-) or with (+) $100 \mathrm{ng} / \mathrm{ml} \mathrm{PTX}$ or $100 \mathrm{ng} / \mathrm{ml} C T X$, stimulated with $100 \mathrm{nM} P$ G for 15 min and nuclear extracts were obtained. Panel C. MCF-7 cells were treated for $1 \mathrm{~h}$ without (-) or with (+) $10 \mu \mathrm{M}$ colchicine or $2.4 \mu \mathrm{M}$ cytochalasin D, stimulated with $100 \mathrm{nM} P G$ for $15 \mathrm{~min}$ and nuclear extracts were obtained. NFKB DNA binding activity was analyzed by EMSA. One control included EMSA reactions with 100 fold-excess of cold $N F \kappa B$ as competitor. The autoradiograms shown are representative of at least three independent experiments.

phosphoinositol lipids, which act as second messengers in several signaling pathways, including the activation of PDK and Akt. The Akt family of serine-threonine kinases is the primary downstream mediator of PI3K, and through the phosphorylation of target substrates mediates a number of cell processes $[24,25]$. Here we demonstrate that PG induces Akt2 activation and that it requires the activity of PI3K and mTOR in MCF-7 cells. We propose that PG plays an important role in the invasion process. Supporting our proposal, it has been demonstrated that in a mouse model of oncogene-induced mammary tumorigenesis, Akt2 participates in tumor invasion and metastasis [26, 27]. Moreover, we previously demonstrated that AA induces migration and invasion through a PI3K/Akt-dependent pathway in MDA-MB-231 breast cancer cells [28].

$\mathrm{NF \kappa B}$ is a transcription factor that plays an important 
role in inflammation, survival, transformation and oncogenesis [29]. Particularly, mammary carcinoma cell lines and human breast cancer tissue present an elevated NF $\kappa$ B DNA-binding activity, whereas rat mammary tumors have high levels of nuclear NFkB DNA binding activity. In addition, transformation of the rat mammary cell line RM22-F5 from an ER positive to an ER negative state is accompanied by a constitutive activation of NFKB [30, 31]. $\mathrm{NF} \kappa \mathrm{B}$ also mediates the expression of cyclin D1 gene, because its promoter contains an NFKB binding site, whereas the overexpression of cyclin D1 in the mammary gland increases the incidence of mammary carcinomas [32, 33]. We demonstrate here that $P G$ induces $N F \kappa B$ DNA-binding activity in a time-dependent manner in MCF-7 cells. In addition, the increase on NFאB DNA binding activity requires the activity of PI3K, Akt and mTOR, as well as the cytoskeleton integrity. We propose that $\mathrm{PG}$ mediates the oncogenic processes through the activation of PI3K/Akt pathway and then NFKB mediates gene expression. Supporting our proposal, it has been demonstrated that NFKB signaling pathway is commonly constitutively activated and that p65 and p50 subunits are frequently overexpressed in breast cancer compared to normal breast tissue [30, 31]. Moreover, cancer cells remodel the cytoskeleton to develop membrane protrusions including filopodia and lamellipodia, whereas PG mediates the remodeling of actin cytoskeleton and the formation of membrane ruffles through an extra-nuclear PG receptor in T-47D breast cancer cells [34-36].

Recently, three progestin receptors unrelated to classical PG receptors and localized in membrane (mPRs), namely $\mathrm{mPR} \alpha, \operatorname{mPR} \beta$ and $\operatorname{mPR} \gamma$ have been described in humans [37]. The mPRs are $7-$ membrane $40 \mathrm{kDa}$ proteins that are unrelated to nuclear steroid receptor and $G$ protein coupled receptor (GPCR) superfamilies, however they belong to the progestin and adiponectin $\mathrm{Q}$ receptor family and mediate signal transduction pathways through $\mathrm{G}$ protein activation $[38,39]$. The mPRs have been identified in human breast cancer biopsies and breast cancer cell lines, including MCF-7, SKBR3 and MDA-MB-468 cells. Particularly, $\mathrm{mPR} \alpha$ mediates epithelial to mesenchymal transition through a PI3K/Akt-dependent pathway [40-42].

The $\mathrm{mPR} \alpha$ activation is coupled with $\mathrm{Gi}$ proteins in MDA-MB-231 and SKBR3 breast cancer cells [41, 43]. CTX is an ADP-ribosyltransferase that modifies the Gs $\alpha$ subunit in the heterotrimeric G proteins, and this ADP ribosylation inhibits GTP hydrolysis by the G protein and maintains the activation of adenylyl cyclase with an increase of cAMP levels, whereas PTX is an inhibitor of Gi/Go proteins [18, 44]. Since, our findings demonstrate that PTX and CTX treatment inhibit the increase of NFאB DNA binding activity induced by $\mathrm{PG}$, we propose that NFאB-DNA complex formation is mediated by Gi and/or Go proteins and that it is inhibited by high levels of cAMP. The cAMP production is mediated by Gs $\alpha$. Moreover, our findings strongly suggest $\mathrm{NF} \kappa \mathrm{B}$ DNA binding activity is mediated by mPRs.
In conclusion, $\mathrm{PG}$ induces Akt2 activation through a PI3K-dependent pathway in MCF-7 breast cancer cells. Moreover, PG also promotes an increase of NFKB DNA binding activity through a PI3K, mTOR, Akt, Src and G-proteins-dependent pathway.

\section{Acknowledgements}

We are grateful to Nora Ruiz for their technical assistance. F. C-G, N. S-M and O. G-H are supported by a Conacyt Predoctoral Training Grant.

\section{Conflict of interest}

The authors have no potential conflicts of interest.

\section{References}

[1] Rossouw JE, Anderson GL, Prentice RL, LaCroix AZ, Kooperberg C, Stefanick ML, et al. Risks and benefits of estrogen plus progestin in healthy postmenopausal women: principal results From the Women's Health Initiative randomized controlled trial. JAMA. 2002;288(3):321-33.

[2] van de Water W, Markopoulos C, van de Velde CJ, Seynaeve C, Hasenburg A, Rea D, et al. Association between age at diagnosis and disease-specific mortality among postmenopausal women with hormone receptor-positive breast cancer. JAMA. 2012;307(6):590-7.

[3] Rakha EA, El-Sayed ME, Green AR, Paish EC, Powe DG, Gee J, et al. Biologic and clinical characteristics of breast cancer with single hormone receptor positive phenotype. J ClinOncol. 2007;25(30):4772-8.

[4] Krantz SB, Shields MA, Dangi-Garimella S, Munshi HG, Bentrem DJ. Contribution of epithelial-to-mesenchymal transition and cancer stem cells to pancreatic cancer progression. J Surg Res. 2012;173(1):105-12.

[5] Ballare C, Uhrig M, Bechtold T, Sancho E, Di Domenico M, Migliaccio A, et al. Two domains of the progesterone receptor interact with the estrogen receptor and are required for progesterone activation of the $\mathrm{c}-\mathrm{Src} / \mathrm{Erk}$ pathway in mammalian cells. Mol Cell Biol. 2003;23(6):1994-2008.

[6] Carnevale RP, Proietti CJ, Salatino M, Urtreger A, Peluffo G, Edwards DP, et al. Progestin effects on breast cancer cell proliferation, proteases activation, and in vivo development of metastatic phenotype all depend on progesterone receptor capacity to activate cytoplasmic signaling pathways. MolEndocrinol. 2007;21(6):1335-58.

[7] Srivastava S, Matsuda M, Hou Z, Bailey JP, Kitazawa R, Herbst MP, et al. Receptor activator of NF-kappaB ligand induction via Jak2 and Stat5a in mammary epithelial cells. J Biol Chem. 2003;278(46):46171-8.

[8] Biswas DK, Iglehart JD. Linkage between EGFR family receptors and nuclear factor kappaB (NF-kappaB) signaling in breast cancer. J Cell Physiol. 2006;209(3):645-52. 
[9] Espinosa-Neira R, Mejia-Rangel J, Cortes-Reynosa P, Salazar EP. Linoleic acid induces an EMT-like process in mammary epithelial cells MCF10A. Int J Biochem Cell Biol. 2011;43(12):1782-91.

[10] Hodgson L, Henderson AJ, Dong C. Melanoma cell migration to type IV collagen requires activation of NF-kappaB. Oncogene. 2003;22(1):98-108.

[11] Alessi DR, Andjelkovic M, Caudwell B, Cron P, Morrice N, Cohen P, et al. Mechanism of activation of protein kinase B by insulin and IGF-1. EMBO J. 1996;15(23):6541-51.

[12] Memmott RM, Dennis PA. Akt-dependent and -independent mechanisms of mTOR regulation in cancer. Cell Signal. 2009;21(5):656-64.

[13] Dillon RL, White DE, Muller WJ. The phosphatidyl inositol 3-kinase signaling network: implications for human breast cancer. Oncogene. 2007;26(9):1338-45.

[14] Ui M, Okada T, Hazeki K, Hazeki O. Wortmannin as a unique probe for an intracellular signalling protein, phosphoinositide 3-kinase. Trends Biochem Sci. 1995;20(8):303-7.

[15] Prasad S, Ravindran J, Aggarwal BB. NF-kappaB and cancer: how intimate is this relationship. Mol Cell Biochem. 2010;336(1-2):25-37.

[16] $\mathrm{Hu} \mathrm{C}$, Huang L, Gest C, Xi X, Janin A, Soria C, et al. Opposite regulation by PI3K/Akt and MAPK/ERK pathways of tissue factor expression, cell-associated procoagulant activity and invasiveness in MDA-MB-231 cells. J HematolOncol. 2012;5:16.

[17] Boonyaratanakornkit V, Scott MP, Ribon V, Sherman L, Anderson SM, Maller JL, et al. Progesterone receptor contains a proline-rich motif that directly interacts with SH3 domains and activates c-Src family tyrosine kinases. Mol Cell. 2001;8(2):269-80.

[18] Moss J, Vaughan M. ADP-ribosylation of guanyl nucleotide-binding regulatory proteins by bacterial toxins. AdvEnzymolRelat Areas Mol Biol. 1988;61:303-79.

[19] Middlebrook JL, Dorland RB. Bacterial toxins: cellular mechanisms of action. Microbiol Rev. 1984;48(3):199-221. Epub 1984/09/01.

[20] Conneely OM, Mulac-Jericevic B, Lydon JP Progesterone-dependent regulation of female reproductive activity by two distinct progesterone receptor isoforms. Steroids. 2003;68(10-13):771-8.

[21] Humphreys RC, Lydon JP, O'Malley BW, Rosen JM. Use of PRKO mice to study the role of progesterone in mammary gland development. J Mammary Gland Biol Neoplasia. 1997;2(4):343-54.

[22] Lee S, Kolonel L, Wilkens L, Wan P, Henderson B, Pike M. Postmenopausal hormone therapy and breast cancer risk: the Multiethnic Cohort. Int J Cancer. 2006;118(5):1285-91.

[23] Manning BD, Cantley LC. AKT/PKB signaling: navigating downstream. Cell. 2007;129(7):1261-74.

[24] Vivanco I, Sawyers CL. The phosphatidylinositol 3-Kinase AKT pathway in human cancer. Nat Rev Cancer. 2002;2(7):489-501.

[25] Liu P, Cheng H, Roberts TM, Zhao JJ. Targeting the phosphoinositide 3-kinase pathway in cancer. Nat Rev Drug
Discov. 2009;8(8):627-44

[26] Dillon RL, Marcotte R, Hennessy BT, Woodgett JR, Mills GB, Muller WJ. Akt1 and akt2 play distinct roles in the initiation and metastatic phases of mammary tumor progression. Cancer Res. 2009;69(12):5057-64.

[27] Hutchinson J, Jin J, Cardiff RD, Woodgett JR, Muller WJ. Activation of Akt (protein kinase B) in mammary epithelium provides a critical cell survival signal required for tumor progression. Mol Cell Biol. 2001;21(6):2203-12.

[28] Villegas-Comonfort S, Castillo-Sanchez R, Serna-Marquez N, Cortes-Reynosa P, Salazar EP. Arachidonic acid promotes migration and invasion through a PI3K/Akt-dependent pathway in MDA-MB-231 breast cancer cells. Prostaglandins LeukotEssent Fatty Acids. 2014. Epub $2014 / 02 / 26$

[29] Cogswell PC, Guttridge DC, Funkhouser WK, Baldwin AS, Jr. Selective activation of NF-kappa B subunits in human breast cancer: potential roles for NF-kappa B2/p52 and for Bcl-3. Oncogene. 2000;19(9):1123-31.

[30] Kim DW, Sovak MA, Zanieski G, Nonet G, Romieu-Mourez R, Lau AW, et al. Activation of NF-kappaB/Rel occurs early during neoplastic transformation of mammary cells. Carcinogenesis. 2000;21(5):871-9.

[31] Nakshatri H, Bhat-Nakshatri P, Martin DA, Goulet RJ, Jr., Sledge GW, Jr. Constitutive activation of NF-kappaB during progression of breast cancer to hormone-independent growth. Mol Cell Biol. 1997;17(7):3629-39.

[32] Hinz M, Krappmann D, Eichten A, Heder A, Scheidereit C, Strauss M. NF-kappaB function in growth control: regulation of cyclin D1 expression and G0/G1-to-S-phase transition. Mol Cell Biol. 1999;19(4):2690-8.

[33] Guttridge DC, Albanese C, Reuther JY, Pestell RG, Baldwin AS, Jr. NF-kappaB controls cell growth and differentiation through transcriptional regulation of cyclin D1. Mol Cell Biol. 1999;19(8):5785-99.

[34] Fu XD, Giretti MS, Baldacci C, Garibaldi S, Flamini M, Sanchez AM, et al. Extra-nuclear signaling of progesterone receptor to breast cancer cell movement and invasion through the actin cytoskeleton. PLoS One. 2008;3(7):e2790.

[35] Yamazaki D, Kurisu S, Takenawa T. Regulation of cancer cell motility through actin reorganization. Cancer Sci. 2005;96(7):379-86.

[36] Yamaguchi H, Wyckoff J, Condeelis J. Cell migration in tumors. CurrOpin Cell Biol. 2005;17(5):559-64.

[37] Zhu Y, Bond J, Thomas P. Identification, classification, and partial characterization of genes in humans and other vertebrates homologous to a fish membrane progestin receptor. ProcNatlAcadSci U S A. 2003;100(5):2237-42.

[38] Tang YT, Hu T, Arterburn M, Boyle B, Bright JM, Emtage $\mathrm{PC}$, et al. PAQR proteins: a novel membrane receptor family defined by an ancient 7-transmembrane pass motif. J MolEvol. 2005;61(3):372-80.

[39] Lyons TJ, Villa NY, Regalla LM, Kupchak BR, Vagstad A, Eide DJ. Metalloregulation of yeast membrane steroid receptor homologs. ProcNatlAcadSci U S A. 2004;101(15):5506-11. 
[40] Zuo L, Li W, You S. Progesterone reverses the mesenchymal phenotypes of basal phenotype breast cancer cells via a membrane progesterone receptor mediated pathway. Breast Cancer Res. 2010;12(3):R34.

[41] Dressing GE, Thomas P. Identification of membrane progestin receptors in human breast cancer cell lines and biopsies and their potential involvement in breast cancer. Steroids. 2007;72(2):111-6.

[42] Thomas P. Characteristics of membrane progestin receptor alpha (mPRalpha) and progesterone membrane receptor component 1 (PGMRC1) and their roles in mediating rapid progestin actions. Front Neuroendocrinol. 2008;29(2):292-312
[43] Thomas P, Pang Y, Dong J, Groenen P, Kelder J, de Vlieg J, et al. Steroid and $G$ protein binding characteristics of the seatrout and human progestin membrane receptor alpha subtypes and their evolutionary origins. Endocrinology. 2007;148(2):705-18.

[44] Peterson JW, Ochoa LG. Role of prostaglandins and cAMP in the secretory effects of cholera toxin. Science. 1989;245(4920):857-9. 